\title{
RELIABILITY OF INFORMATION ON VARICELLA HISTORY IN PRESCHOOL CHILDREN
}

\author{
Lúcia Ferro Bricks, Cláudio Sérgio Pannuti, Helena Keico Sato, Eneida S. Ramos \\ Vico, Adriana Melo de Faria, Vanda V.A.U. Souza, Laura M. Sumita, Isabel de \\ Camargo Costa, Evandro Roberto Baldacci
}

Bricks LF, Pannuti CS, Sato HK, Vico ESR, Faria AM, Souza VVAU, Sumita LM, Costa IC, Baldacci ER. Reliability of information on varicella history in preschool children. Clinics. 2007;62(3):309-14.

OBJECTIVE: To verify how reliable is the information provided by parents about the history of varicella in their children. METHODS: 204 parents of previously healthy children attending two municipal day-care centers of São Paulo city were interviewed between August 2003 and September 2005. A standardized form was filled out with information regarding age, sex, history of varicella and other diseases, drug use and antecedent of immunization, After medical history, physical examination and checking of immunization records, $5 \mathrm{ml}$ of blood were collected for ELISA (in house) varicella test. Exclusion criteria were: age less than 1 year or more than 60 months, previous immunization against chickenpox, presence of co-morbidities or recent use of immunosuppressive drugs. Data were filed in a data bank using the Excel 2003 Microsoft Office Program and stored in a PC computer. The exact Fisher test was employed to calculate sensibility, specificity, positive and negative predictive values of history of varicella informed by children's parents.

RESULTS: The age of the children varied from 12 to 54 months (median, 26 months; 49 (24\%) children had positive history of varicella, $155(76 \%)$ a negative or doubtful history. The predictive positive and negative values of the information were $90 \%$ and $93 \%$, respectively $(\mathrm{p}=0.0001)$.

CONCLUSIONS: The degree of reliability of information about history of varicella informed by parents of children attending day care centers was high and useful to establish recommendations on varicella blocking immunization in day-care centers.

KEYWORDS: Varicella-Zoster. Children. Day-care centers.

\section{INTRODUCTION}

The cause of varicella is the varicella-zoster (VVZ) virus that affects humans and a few higher primates. The primary infection develops the varicella condition (pox rash), which is characterized by the outburst of papulovesicular exanthematic lesions that are polymorphic, with central distribution. On the other hand, virus reactivation is the cause of herpes zoster. The disease is spread worldwide and when

Children's Institute, Hospital das Clínicas, Faculty of Medicine, University of Sao Paulo/ SP, Brazil

Institute of Tropical Medicine, Faculty of Medicine, University of Sao Paulo/ SP, Brazil

Email: Ifbricks@gmail.com

Received for publication on November 24, 2006

Accepted for publication on February 23, 2007. no vaccination program is in place, most cases will occur during childhood.

In previously healthy children, varicella is an acute and self-limiting disease, with low degree of fatality; however, morbidity is high and may give rise to different complications, including death ${ }^{1-6}$. Adults and those with underlying diseases are at greater risk for complications. However, in absolute figures, most of the complications, hospitalizations, and deaths have been reported in previously healthy children ${ }^{7-11}$.

Recent studies have indicated that children in day-care units are at greater risk for complications and death from varicella $^{8-10}$. In the State of São Paulo, as of September 2003, the State Health Secretary has recommended blockade vaccination in day-care centers as soon as the first case of vari- 
cella is reported ${ }^{12}$. The vaccine is recommended for children over one year of age and for adults with negative or doubtful varicella history without a prior serologic test ${ }^{2}$.

Although a few studies have assessed the positive and negative predictive value of the information on the varicella antecedents in children and adults ${ }^{13-19}$, no study was found in the literature assessing the reliability of the information provided by parents of children attending Government day-care centers in the State of São Paulo. Thus, it was decided to conduct this study, because such information is critical in order to establish appropriate public policies to develop vaccination guidelines.

\section{Objectives}

To assess the sensitivity and specificity of the information provided by parents on their children's varicella history, at daycare center, by comparing their information with serological tests (ELISA, in house technique) and their corresponding positive (PPV) and negative (NPV) predictive value.

\section{Casuistics and Methods}

This was a cross-sectional study covering the period of August 2003 to September 2005, conducted as an investigation of varicella history with parents or caretakers of children in the age group 12 to 60 months who attended two municipal day-care units in São Paulo. Blood collection for the performance of ELISA serologic tests was carried out in these children.

\section{Population}

The study field included two municipal day-care units located in the west district of the city of São Paulo, that cater for a population in which family income is lower than three minimum monthly wages (roughly equivalent US\$550.00 per month take home money). The units were selected as a convenient sample, because they are located close to the Research Centers (laboratory and hospital) involved in this study.

The universe was exclusively composed of previously healthy children, aged between 12 and 60 months, whose parents freely consented to take part in the study. Children previously vaccinated against varicella and those with diseases that could affect immunity or who had been given oral corticosteroids during the last three months were excluded.

\section{METHODS}

After approval by the Ethics Committee/Institutitonal
Review Board of the Institutions involved in the investigation, the Project was presented to the Day-Care Units Board. The study objective and procedures were detailed to the children's caretakers in different meetings, each gathering 20 parents. After signing the Free and Informed Consent Form, parents, under the supervision of the investigator, filled out a previously tested form with data on age, gender, disease history, use of medications and the child's vaccinal status.

Later, on pre-set dates, anamnesis, physical exams and blood collection were performed. Anti-VVZ antibodies were detected by an in-house ELISA test that has been tested and described in another study ${ }^{8}$.

\section{Inclusion Criteria}

Children from 12 to 60 months of age, without prior varicella vaccination and no disease or drug use that could hamper the immunologic response.

\section{Exclusion Criteria}

Children with less than 12 or more then 60 months of age, prior varicella vaccination, disease or use of drugs affecting immunity, missed material collection visit, and failure to obtain parent's informed consent.

\section{Procedures}

On the blood collection set date, the study investigators performed anamnesis, physical exams and reviewed the children vaccination records. Children with negative or doubtful history of varicella were vaccinated soon after blood collection, provided there was no condition that would contraindicate such vaccination.

\section{Data Base and Statistical Analysis}

The following variables were reviewed: gender, age, varicella history and vaccinal status.

All the information collected were entered in a data bank using the Excel 2003 Microsoft Office Program and filed in a PC computer.

The statistical analysis was based on frequency distribution in absolute values and in percentages, average and median. The exact Fisher test was used to calculate sensitivity (Se), specificity (Sp), positive (PPV) and negative (NPV) predictive value with $95 \%$ confidence interval $(\mathrm{CI}),(\mathrm{P}<0.05)$.

\section{OUTCOME}

The information collected from 204 children was re- 
Table 1 - Distribution of 204 children included in the study according to gender and age. São Paulo Municipality, August 2003 to September 2005.

\begin{tabular}{|c|c|c|c|c|c|c|}
\hline \multirow{2}{*}{$\begin{array}{l}\text { Age Group } \\
\text { (in months) }\end{array}$} & \multicolumn{2}{|c|}{ Girassol Day-Care Center } & \multicolumn{2}{|c|}{ São José Day-Care Center } & \multicolumn{2}{|c|}{ Total } \\
\hline & Male & Female & Male & Female & Male & Female \\
\hline $12-23$ & 25 & 17 & 21 & 21 & 46 & 38 \\
\hline $24-35$ & 18 & 23 & 12 & 10 & 30 & 33 \\
\hline $36-49$ & 16 & 11 & 18 & 8 & 34 & 19 \\
\hline $50-60$ & - & 1 & 1 & 2 & 1 & 3 \\
\hline Total & 59 & 52 & 52 & 41 & 111 & 93 \\
\hline
\end{tabular}

viewed. Out of this total, 49 children $(24 \%)$ had positive antecedents for varicella, and $155(76 \%)$, negative $(\mathrm{n}=142)$ or doubtful $(\mathrm{n}=13)$ antecedents.

Data on gender and age group distribution of the children enrolled in the two day-care units is reported in Table 1.

Out of the total of 49 children who reported a positive history, only five children (10\%) exhibited negative serology and out of 155 children with negative or doubtful history, 11 (7\%) exhibited positive serology (Table 2).

The sensitivity of the information was 0.80 (CI 95\%: 0.67-0.89) and the specificity was 0.97 (CI 95\%: $0.92-$ 0.99 ). The information positive predictive value was 0.90 (CI95\%: $0.78-0.97)$ and the negative predictive value was 0.93 (CI 95\%: $0.88-0.96$ ).

Taking into account only the group of children whose parents indicated having no doubts on either positive or negative varicella history, sensitivity increased to 0.88 and specificity continued at 0.97 as shown in Table 3.

Table 2 - Distribution of children included in the study (n) according to their parents' information on varicella history and serological response. São Paulo Municipality, August 2003 to September 2005.

\begin{tabular}{lccc}
\hline Varicella History & $\begin{array}{c}\text { Positive } \\
\text { Serology } \\
\mathrm{n}\end{array}$ & $\begin{array}{c}\text { Negative } \\
\text { Serology } \\
\mathrm{n}\end{array}$ & $\begin{array}{c}\text { Total } \\
\mathrm{n}(\%)\end{array}$ \\
\hline Positive & 44 & 5 & $49(24)$ \\
Negative or Doubtful & 11 & 144 & $155(76)$ \\
Total & 55 & 149 & $204(100)$ \\
\hline
\end{tabular}

Table 3 - Distribution of children* (n) whose parents claimed to be sure about varicella antecedents. Distribution according to serologic tests. São Paulo Municipality, August 2003 to September 2005.

\begin{tabular}{lccc}
\hline $\begin{array}{l}\text { Varicella } \\
\text { Antecedents }\end{array}$ & $\begin{array}{c}\text { Positive } \\
\text { Serology } \\
\mathrm{n}\end{array}$ & $\begin{array}{c}\text { Negative } \\
\text { Serology } \\
\mathrm{n}\end{array}$ & $\begin{array}{c}\text { Total } \\
\mathrm{n}(\%)\end{array}$ \\
\hline Positive & 44 & 5 & $49(26)$ \\
Negative & 6 & 136 & $142(74)$ \\
Total & 50 & 141 & $191(100)$ \\
\hline
\end{tabular}

* Excluding 13 cases whose information was doubtful.

\section{DISCUSSION}

Very few studies on the reliability of information on children's varicella history are available ${ }^{15-19}$. The majority of the published investigations was carried out to assess the positive and negative predictive value of the information on varicella history and include children older than seven, adolescents and adults.

Young adults with varicella negative antecedents generally show positive serology for the disease ${ }^{13,14}$. Lieu et al (1998) ${ }^{15}$ reported that varicella antibodies seroprevalence in children between 7 and 12 years of age with negative or uncertain varicella history varied between $9 \%$ and $68 \%$ and grew with the child's increasing age. Despite the low level of reliability of the information on negative varicella history, the level of reliability of the family's information on varicella's positive antecedents was high (95\%).

In two recent studies, designed to assess parent's information reliability in connection with varicella history in young refugees of different countries, it was reported that the positive predictive value was high $(88 \%$ to $100 \%)$ while the negative predictive value was low (28 to $66 \%$ ) ${ }^{18,19}$.

In this study, information on positive and negative history of the disease was considered reliable. This is probably due to the high prevalence of varicella in children, especially among those attending day-care centers, because they get an earlier exposure to the disease ${ }^{20}$. Besides, the ages of children with negative (median $=22$ months; range 12 - 52 months) and positive antecedent for varicella (median $=38$ months; range $15-52$ months) were low, and probably the risk of a memory bias was low too.

The varicella vaccine is highly effective against serious forms of the disease, although protection against mild forms is not as good (80\%) ${ }^{1,21-24}$.

Varicella is a highly contagious disease, particularly after close contact in the household or in collective environments such as day-care centers ${ }^{25,26}$. The São Paulo Health State Secretary's recommendation to vaccinate children enrolled in day-care units is due to the higher death rate in this group ${ }^{10}$.

In 2003 , some 60,000 cases of varicella were reported 
in the State of São Paulo, of which 60 were fatal. Although $50 \%$ of the cases reported involved children younger than five, about $80 \%$ of the death cases were reported in children in this age-group ${ }^{12}$.

Despite the fact that this trial indicated that information on varicella history in younger children is highly reliable to establish a vaccination program, it is critical to remember that immunization after a close contact is only effective if administered promptly, i.e. up to 72 hours after the index case has been detected. In addition, because varicella is highly transmissible indoors, a high vaccinal coverage is required to prevent the spread of the disease in daycare centers ${ }^{1}$.

A blocking vaccination program in day-care units is rather complex, as it requires prompt information conveyance, a survey of the children health conditions and of their vaccination status in addition to trained staff available to vaccinate in day-care units.

In different countries, varicella vaccination cost-benefit studies have demonstrated that vaccination can be resource saving, especially when taking into account the social costs of the disease, such as parents' labor absenteeism 1,5,27-29. We are not aware of any study conducted in Brazil to assess varicella vaccination cost-benefits. Nevertheless, the number of death cases and complications due to varicella in previously healthy children is not negligible, and effective measures to control the disease are necessary.

Finally, it should be pointed out that the acceptance of new vaccines by the population depends on the level of information delivered to the parents concerning the safety and efficacy of such vaccines. All the parents who took part in this trial did receive information on the vaccine and on the disease and gave their consent for their children's vaccination ${ }^{30-32}$.

There are two aspects that offer a potential bias in this study: the smaller number of children with positive varicella history as compared to those with negative antecedents and the ELISA test sensitivity to detect prior varicella occurrence. Most of the children who were not included in the study were children with a varicella positive history, whose parents refused to allow blood to be drawn. Despite this screening bias, the children universe analyzed was representative and helped in drawing the conclusion that both positive and negative information were highly reliable $(\mathrm{P}<0.001)$.

As to the serological test, although the ELISA test is not considered the gold standard to help establish if the child has or has not had the disease, it does exhibit good sensitivity and specificity for varicella diagnosis and is the most commonly used method in research, because it is easier to perform than FAMA's ${ }^{33}$.

\section{CONCLUSIONS}

The reliability of the information on varicella history in preschool children was high and useful as a guideline for blockade vaccination programs in day-care centers.
Bricks LF, Pannuti CS, Sato HK, Vico ESR, Faria AM, Souza VVAU, Sumita LM, Costa IC, Baldacci ER. Confiabilidade da informação sobre antecedente de varicela em crianças pré-escolares. Clinics. 2007;62(3):309-14.
OBJETIVOS: Verificar o grau de confiabilidade da informação fornecida pelos pais de crianças atendidas em creches sobre o antecedente de varicela.

MÉTODOS: Os pais de 204 crianças previamente saudá- 
veis matriculadas em duas creches da cidade de São Paulo foram entrevistados entre Agosto de 2003 e Setembro de 2005 para preenchimento de um questionário padronizado com informações sobre idade, sexo, antecedente de varicela e outras doenças, uso de medicamentos e história vacina. Após anamnese, exame físico e verificação da carteira de vacinação, foram colhidos $5 \mathrm{ml}$ de sangue para realização do teste ELISA (in house) para varicela. Os critérios de exclusão foram: idade $<1$ ano ou acima de 60 meses, vacinação prévia contra varicela, presença de comorbidades e uso recente de imunossupressores. Os dados foram registrados num banco de dados do programa Excel 2003 Microsoft Office e armazenados em microcomputador. Utilizou-se o teste exato de Fisher para calcular a sensibilidade, especificidade e valores preditivo po- sitivo e negativo das informações fornecidas pelos pais sobre o antecedente de varicela das crianças.

RESULTADOS: A idade das crianças variou entre 12 e 54 meses (mediana, 26 meses); 49 crianças (24\%) tinham antecedente positivo para varicela e 155 (76\%) negativo ou duvidoso. Os valores preditivo positivo e negativo da informação foram de $90 \%$ e $93 \%$, respectivamente $(\mathrm{p}=$ $0.0001)$.

CONCLUSÕES: O grau de confiabilidade das informações sobre varicela informadas pelos pais de crianças atendidas em creches foi elevado e útil para estabelecer recomendações para vacinação de bloqueio de surtos de varicela em creches.

UNITERMOS: Varicela-zóster. Crianças. Creches.

\section{REFERENCES}

1. Gershon AA, Takahashi M, Seward J. Varicella vaccine. In: Plotkin SA, Orenstein WA, Offit PA. ed. Vaccines. 4 ed, Philadelphia: WB Saunders; 2004. p.783-823.

2. National Advisory Committee on Immunization (NACI) update on varicella. Can Commun Dis Rep. 2004; 1; 30:1-26.

3. Rentier B, Gershon AA, Members of EuroVar Consensus: Varicella vaccination of healthy children: a challenger for Europe. Pediatric Infect Dis J. 2004; 23:379-89.

4. Banz K, Wagenpfeil S, Neiss A, Hammerschmidt T, Wutzler P. The burden of varicella in Germany. Potential risks and economic impact. Eur J Health Econ. 2004; 5:46-53.

5. Gidding HF, MacIntyre CR, Burgess MA, Gilbert GL. The seroepidemiology and transmission dynamics of varicella in Australia. Epidemiol Infect. 2003; 131:1085-9.

6. Clemens SAC, Azevedo T, Fonseca JC, Silva AMC, Silveira T, Clemens R. Soroepidemiologia da varicela no Brasil: resultados de um estudo prospectivo transversal. J Pediatr (Rio J). 1999; 75:433-41.

7. Peterson Cl, Mascola L, Chao SM, Lieberman JM, Arcinue EL, Blumberg DA. Children hospitalized for varicella: a prevaccine review. J Pediatr. 1996; 129:529-36.

8. Yu Alf, Costa JM, Amaku M, Pannuti CS, Souza VAUF, Zanetta DMT. Three year seroepidemiological study of varicella-zoster virus in São Paulo, Brazil. Rev Inst Med Trop S. Paulo. 2000; 42:125-8.

9. Ziebold C, Von Kries R, Lang R, Weigl J, Schmitt HJ. Severe complications of varicella in previously healthy children in Germany: a 1-year survey. Pediatrics. 2001; 108:e79.
10. Baldacci ER, Vico ESR. Mortalidade por varicela em crianças atendidas em creche. Pediatria (São Paulo). 2002; 23:213-6.

11. Diez-Domingo J, Aristegui J, Calbo F, Gonzalez-Hachero J, Moraga F, Pena Guitian J et al. Epidemiology and economic impact of varicella in immunocompetent children in Spain. A nation-wide study. Vaccine. 2003; 21:3236-9.

12. São Paulo. Secretaria de Estado da Saúde de São Paulo. Centro de Vigilância Epidemiológica "Alexandre Vranjac" Vacinação contra varicela em creches. Accessed at: www.cve.saude.sp.gov.br.

13. Jerant AF, DeGaetano JS, Epperly TD, Hannapel AC, Miller DR, Lloyd AJ. Varicella susceptibility and vaccination strategies in young adults. $\mathrm{J}$ Am Board Fam Pract. 1998; 11:296-306.

14. Lerman Y, Chodick G, Tepper S, Livni G, Ashkenazi S. Seroepidemiology of varicella-zoster virus antibodies among healthcare workers and day-care-centre workers. Epidemiol Infect. 2004; $132: 1135-8$.

15. Lieu TA, Black SB, Takahashi H, Ray P, Capra AM, Shinefield HR et al. Varicella serology among school age children with a negative or uncertain history of chickenpox. Pediatr Infect Dis J. 1998; 17:120-5.

16. Boulianne N, Duval B, De Serres G, Deceuninck G, Masse R, Couillard M. Most ten-year-old children with negative or unknown histories of chickenpox are immune. Pediatr Infect Dis J. 2001; 20:1087-8.

17. Kavaliotis J, Petridou S, Karabaxoglou D. How reliable is the history of chickenpox? Varicella serology among children up to 14 years of age. Int J Infect Dis. 2003; 7:274-7. 
18. Figueira M, Christiansen D, Barnett ED. Cost-effectiveness of serotesting compared with universal immunization for varicella in refugee children from six geographic regions. J Travel Med. 2003;10:203-7

19. Christiansen D, Barnett ED. Comparison of varicella history with presence of varicella antibody in refugees. Vaccine. 2004; 22: 4233-7.

20. Marcitelli R, Bricks LF. Varicella zoster in children attending day care centers. Clinics. 2006; 61:147-52.

21. Buff AM, Welch FJ, Tapia RA. A review of varicella vaccine and Louisiana vaccination requirements. J La State Med Soc. 2004; 156:505.

22. Davis MM, Patel MS, Gebremariam A. Decline in varicella-related hospitalizations and expenditures for children and adults after introduction of varicella vaccine in the United States. Pediatrics. 2004; 114: $786-92$

23. Krysan DJ. Effectiveness over time of varicella vaccine. Pediatr.2004; 145:416-7.

24. Kuter B, Matthews H, Shinefield H, Black S, Dennehy P, Watson B et al. Ten year follow-up of healthy children who received one or two injections of varicella vaccine. Pediatr Infect Dis J. 2004; 23:132-7.

25. Seward JF, Zhang JX, Maupin TJ, Mascola L, Jumaan AO. Contagiousness of varicella in vaccinated cases: a household contact study. JAMA. 2004; 292:704-8.
26. Asano Y, Yoshikawa T, Kanematsu M, Ihira M, Suzuki K, Suga S. Rapid contamination with varicella-zoster virus DNA to the throat of a daycare attendee and environmental surfaces from a child with varicella. Pediatr Inter.1999; 41, 233-6.

27. Ferson MJ, Shen WL, Stark A. Direct and indirect cost of chickenpox in young children MMWR Morb Mortal Wkly Rep. 1998;34:18-21.

28. Pena-Rey I, Perez-Farinos N, Cortes-Garcia M, Amela-Heras C. [Costeffectiveness of varicella vaccination in Spanish adolescents] Gac Sanit. 2004; 18:287-94.

29. Thiry N, Beutels P, Tancredi F, Romano L, Zanetti A, Bonanni P et al An economic evaluation of varicella vaccination in Italian adolescents. Vaccine. 2004 9; 22:3546-62.

30. Schaffer SJ, Bruno S. Varicella immunization practices and the factors that influence them. Arch Pediatri Adolesc Med 1999 153:326-7.

31. Milledge JT, Cooper CD, Woolfenden S. Barriers to immunization: attitudes of general practitioners to varicella, the disease and its vaccine. Paediatr Child Health. 2003; 39:368-71.

32. de Courval FP, De Serres G, Duval B. Varicella vaccine: factors influencing uptake. Can J Public Health. 2003; 94:268-71.

33. Krah DL. Assays for antibodies to varicella-zoster virus. Infect Dis Clin North Am. 1996; 10:507-27. 